\title{
Geomats Used to Control Erosion on Reservoir Margins in Brazilian Hydroelectric Power Plants
}

\author{
Marta Pereira da Luz ${ }^{1,2,3}$ (D), Maria Alejandra Aparicio Ardila ${ }^{3, *}$ (D) Ricardo D. dos Santos Junior ${ }^{3}$, \\ Clever A. Valentin ${ }^{3}{ }^{\mathbb{D}}$, Marlon S. Schliewe ${ }^{1} \mathbb{D}$, Arnaldo T. Coelho ${ }^{4}$ and Jefferson Lins da Silva ${ }^{3}$ \\ 1 Eletrobras, Furnas Centrais Elétricas S.A., Aparecida de Goiânia, Goiás 74923-650, Brazil; \\ martaluz@furnas.com.br or martaluz@sc.usp.br (M.P.d.L.); marlonss@furnas.com.br (M.S.S.) \\ 2 Industrial and Systems Engineering Postgraduate Program (MEPROS), Pontifical Catholic University of \\ Goiás, Goiânia 74605-010, Brazil \\ 3 São Carlos School of Engineering (EESC), University of São Paulo, São Carlos, São Paulo 13566-590, Brazil; \\ ricardo.domingos.santos@usp.br (R.D.d.S.J); cclever@sc.usp.br (C.A.V.); jefferson@sc.usp.br (J.L.d.S.) \\ 4 Ingá Engenharia e Consultoria, Belo Horizonte 30320-130, Brazil; arnaldo@ingaengenharia.com.br \\ * Correspondence: maparicio@usp.br; Tel.: +55-16-33-73-8220
}

Citation: da Luz, M.P.; Aparicio Ardila, M.A.; dos Santos Junior, R.D.; Valentin, C.A.; Schliewe, M.S.; Coelho A.T.; Lins da Silva, J. Geomats Used to Control Erosion on Reservoir Margins in Brazilian Hydroelectric Power Plants. Water 2021, 13, 1444. https://doi.org/10.3390/w13111444

Academic Editor: Iacopo Carnacina

Received: 9 March 2021

Accepted: 9 May 2021

Published: 21 May 2021

Publisher's Note: MDPI stays neutral with regard to jurisdictional claims in published maps and institutional affiliations.

Copyright: (c) 2021 by the authors. Licensee MDPI, Basel, Switzerland. This article is an open access article distributed under the terms and conditions of the Creative Commons Attribution (CC BY) license (https:// creativecommons.org/licenses/by/ $4.0 /)$.

\begin{abstract}
Erosion on reservoir margins causes losses in the production of energy in Hydroelectric Power Plants (HPPs), making it necessary to implement control techniques that ensure the reduction in sediment deposits inside reservoirs. Among these techniques, geomats (geosynthetic erosion mats) are widely used to control erosion processes in slopes and watercourses. This material protects the margins both in the short and long term, contributing to strengthening the vegetation's roots developed in the erosion areas. This paper studies the performance of geomats (with and without sack gabion) installed in six margin sections distributed in three experimental units of the Brazilian HPPs called Porto Colômbia and Volta Grande. The geomat performance was evaluated over four years of monitoring through a qualitative evaluation matrix and differential bathymetry. The influence of ultraviolet (UV) radiation on the degradation of geomats installed in each section (natural conditions), as well as on geomat ultraviolet-aging samples in the laboratory (accelerated conditions), was also evaluated using differential scanning calorimetry (DSC). The results showed no significant difference in performance between using the erosion control technique consisting only of geomats and the technique consisting of geomats and sack gabion. The highest bathymetric difference value obtained in the present study was $1.62 \mathrm{~m}$ in the experimental unit VG1, controlled with geomat without the application of sack gabion on the margin.
\end{abstract}

Keywords: geomat; sack gabion; geosynthetics; erosion control techniques; reservoir margins

\section{Introduction}

Excess sediment in watercourses is the most common contaminant on the planet. Economic and social losses and the growing reduction in productive land and navigable watercourses exceed losses caused by the release of pollutants and toxic waste. This problem is exacerbated as we move downstream towards coasts and population centers [1]

Soil erosion caused by water is the most representative type of erosion and has become an important research topic [2]. This type of erosion is one of the main threats to soils, negatively impacting ecosystem services, agricultural production, drinking water, and carbon stocks. Besides, it is responsible for the most significant soil loss in regions such as Europe compared to other erosion processes (for example, wind erosion) [3]. Erosion is a problem that can cause damage to civil infrastructure and the silting up of natural and artificial reservoirs for water supply and hydroelectric power generation. Therefore, it is crucial to prevent and control erosion, minimizing its consequences [4]. Controlling erosion entails curbing, reducing, or restricting (not stopping completely) the gradual or sudden wear and tear of the soil. Soil loss (erosion) is a process that occurs continuously 
in natural ecosystems, as well as in recovered sites [1], caused by natural or human-made processes. The most common and natural element used to control erosion is vegetation, which helps absorb water that the soil cannot handle and protects the soil from the direct incidence of wind, thereby preventing erosion [5]. Vegetation significantly controls erosion rates, which decrease exponentially with increasing vegetation cover $[6,7]$.

Although vegetation is the most used element for erosion control, it takes several seasons (time) to establish itself fully. Therefore, during the initial stages of growth (when the exposure of erosion processes is high), geosynthetics are presented as auxiliaries of vegetation to control erosion processes [5]. Geosynthetics can be used in the short and long term, as they are made of durable polymeric materials with specific formulations. They can last for many years depending on their application; when used in critical applications, they have a service life of 300 years or even more [6,8]. The durability of the material in terms of its service life is essential as it will be exposed to several environmental factors.

Geosynthetics have been gaining ground as erosion control elements since 1958 when a 'plastic cloth' was used in place of a granular filter to prevent sand from escaping behind concrete blocks used for coastal protection [1]. They are used in interventions to prevent erosion of slopes or channels where energy demands are not particularly strong. The application of recycled polymeric materials (geosynthetics) and fibers mixed with local soil to control erosion processes has also gained prominence in recent years, as in the work of Broda et al. [9]. They used these techniques to protect a steep slope exposed to intensive rill erosion in a region of Poland. There are also options for more environmentally friendly geosynthetics, such as jute geotextile, treated with antimicrobial chemicals and used as a substitute for traditional geosynthetics [10]. Furthermore, geosynthetics from biodegradable polyester are used in specific seasonal or temporary applications [11]. Geosynthetics have brought many benefits in erosion control applications. However, it is essential to consider the long-term environmental impacts caused by their use [12], as geosynthetics are generally made from non-biodegradable polymers.

One of the most widespread erosion control techniques entails placing natural materials (biomats) or geosynthetic erosion mats (geomats) [13]. These techniques can be considered bioengineering techniques. Bioengineering is a technique that combines the use of vegetation with other materials and has gained high popularity in the world in recent decades due to its low environmental impact [14].

Geomats are biotechnical composites manufactured with non-degradable materials that provide temporary passive protection against erosion before vegetation growth (short term). Finally, they become synergistically entangled with the vegetation, reinforcing vegetation performance (long term). The faster the vegetation is established, the better results the erosion control technique presents $[1,13]$. Research conducted in the laboratory has confirmed that shear strength and cohesion of the geomat-soil interface can be significantly improved by reinforcement combined with roots [15]. Lejcus et al. [16] carried out studies with other types of geocomposites (water-absorbing geocomposites), different from geomats. The study indicated increases in shear resistance of soil covered by roots in different vegetation types (66.7\% for shrubs and $20.1 \%$ for grasses). A study carried out by $\mathrm{Xu}$ et al. [17] on an earthen levee subjected to different scenarios indicated that geomats could significantly improve the stability of the levee during hurricane overtopping conditions involving storm surge and wind-generated wave action. Geomats exercise reliable control of topsoil erosion for slopes of different lengths and gradients [18]. In practice, the efficiency of bioengineering methods can be improved by controlling the variation in root cohesion [19].

Geomats have been increasingly used as an environmental protection material for slopes and margins due to their low cost and simple, rapid construction [20]. Nowadays, when time and economy are the most important criteria to find a solution, decision-makers and designers must select a quick installation technique that ensures reliability in its performance and, most importantly, is inexpensive and does not require specialized labor. Laboratory and field research has confirmed the effectiveness of geomats in protecting 
against erosive processes in general $[4,5,15,20]$. However, there is still little research carried out in the field that has conducted constant monitoring of the techniques, as is the case of the present work, which has been monitoring the performance of geomats over a 4-year study period.

Erosion is a process common in tropical regions such as Brazil. Problems caused by soil erosion both on reservoir margins and hydroelectric power plant (HPP) slopes have been commonly faced by Eletrobras Furnas, which is a mixed Brazilian economy private power generation company [4]. Eletrobras Furnas has carried out several studies on its HPPs, including that of Vianna et al. [12], who analyzed plant development in different bioengineering techniques applied on slopes, and that of Aparicio Ardila et al. [21], who analyzed the performance of semi-rigid erosion control techniques (gabion/gabion mattress and geogrid mattress) on the reservoir margins of the HPPs. In addition to field research, laboratory research, such as that performed by Melo et al. [4], who evaluated the performance of geosynthetics in erosive processes caused by high-intensity rainfall, is of great importance. It is also essential to consider other erosion control techniques, such as biological restoring, studied by Hashim et al. [22]. They evaluated the impact of biological soil crusts (Cyanobacteria and Chlorophyte on the behavior of soil sample erodability parameters collected on the bank of the Tigris River in Iraq.

Due to the importance of erosion in environmental and economic terms, the main objective of this study was to investigate the performance of geomats and geomats with sack gabion used in erosion control in different sections of three experimental units located on the reservoir margins of the HPPs called Porto Colômbia and Volta Grande. This work is a continuation of the research developed by Aparicio Ardila et al. [21]. They evaluated the performance of erosion control techniques different from those analyzed in the present study, only implemented in the same HPPs (Porto Colombia and Volta Grande). Moreover, they evaluated the degradation of the geotextile used in the techniques through thermal analysis (thermogravimetry (TG) and differential scanning calorimetry (DSC) analyses). In the present work, thermal analysis was performed on geomats exposed to UV radiation in the field and aged in the laboratory, using DSC.

\section{Materials and Methods}

\subsection{Study Area}

The experimental units (EUs) are located on the margins of the HPPs called Porto Colombia (with two EUs-PC1 and PC2) and Volta Grande (with one EU-VG), as can be seen in Figure 1. These HPPs are among the 13 HPPs built along the course of the Rio Grande on the border of São Paulo and Minas Gerais states [23]. Agricultural activities are carried out on the margins of the study area. The region is also known for having second vacation homes $[23,24]$. The characterization and soil strength test results for the three experimental units are shown in Table 1. According to the Köppen climate classification, the study areas' climate is classified as Cwa [25] and has an average annual precipitation of $1011 \mathrm{~mm}$, an average annual temperature of $23.5^{\circ} \mathrm{C}$, and temperatures ranging between $16.4{ }^{\circ} \mathrm{C}$ and $38.6^{\circ} \mathrm{C}[21]$.

Table 1. Geotechnical characteristics of the experimental units.

\begin{tabular}{|c|c|c|c|c|}
\hline \multirow{2}{*}{ Characteristic } & \multicolumn{3}{|c|}{ Value } & \multirow{2}{*}{ Standard } \\
\hline & UE1 Porto Colômbia & UE2 Porto Colômbia & UE Volta Grande & \\
\hline Specific gravity of soil solids $\left(\rho_{s}\right)$ & $2.896 \mathrm{~g} / \mathrm{cm}^{3}$ & $2.855 \mathrm{~g} / \mathrm{cm}^{3}$ & $2.865 \mathrm{~g} / \mathrm{cm}^{3}$ & NBR 6458 [26] \\
\hline$\%$ of Sand & $25.7 \%$ & $17.9 \%$ & $15.2 \%$ & \\
\hline$\%$ of Silt & $24.9 \%$ & $30.6 \%$ & $27.5 \%$ & NBR 7181 [27] \\
\hline$\%$ of Clay & $49.5 \%$ & $51.6 \%$ & $57.3 \%$ & \\
\hline Soil classification & Sandy silt (ML) & Sandy silt (ML) & Sandy silt (ML) & $\begin{array}{c}\text { NBR 7181 [27] } \\
\text { ASTM D 2487-17 [28] }\end{array}$ \\
\hline Liquid limit (LL) & $43 \%$ & $40 \%$ & $47 \%$ & NBR 6459 [29] \\
\hline Plastic limit (PL) & $34 \%$ & $32 \%$ & $38 \%$ & NBR 7180 [30] \\
\hline Plasticity index (PI) & $9 \%$ & $9 \%$ & $9 \%$ & - \\
\hline
\end{tabular}




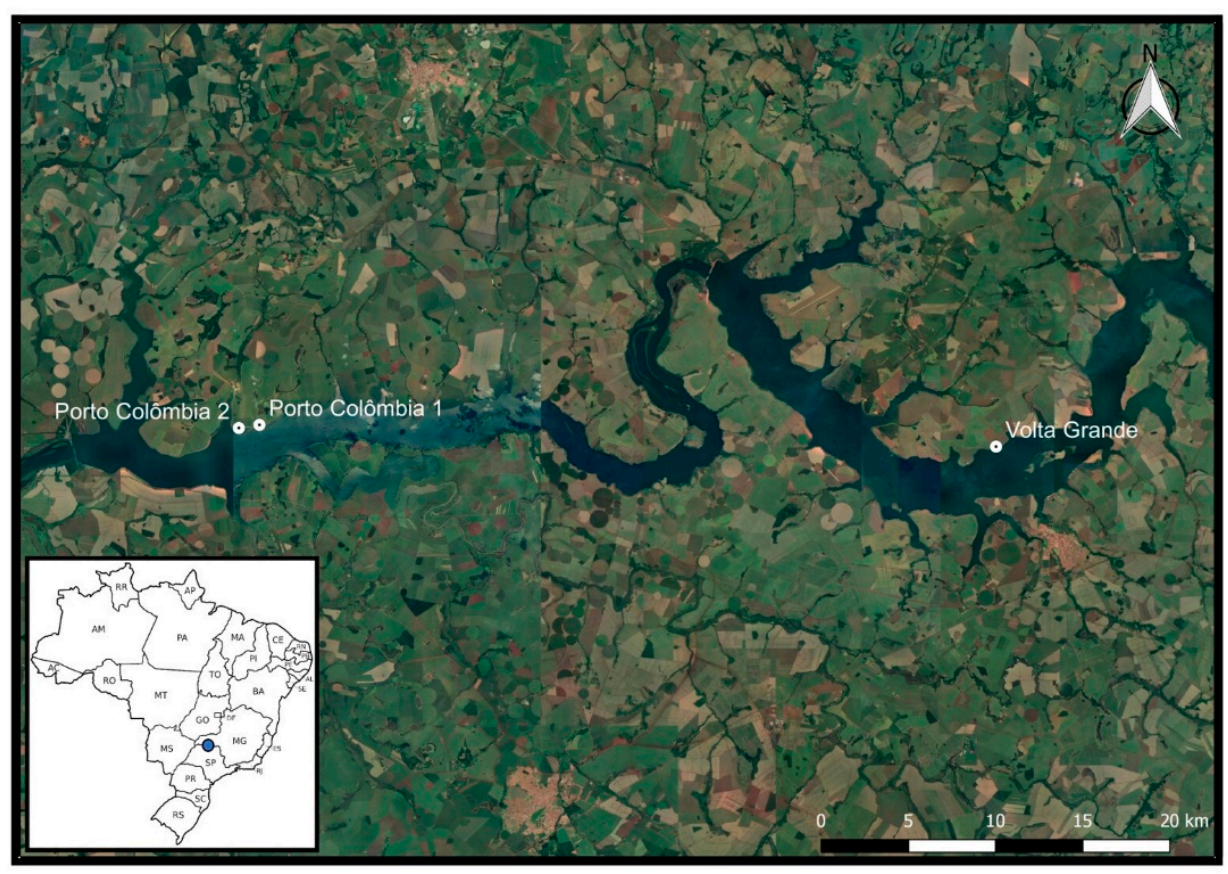

Figure 1. Location of the experimental units (EUs) in the hydroelectric power plants: Porto Colômbia $1\left(20^{\circ} 6^{\prime} 55.82^{\prime \prime} \mathrm{S} ; 48^{\circ} 28^{\prime} 9.07^{\prime \prime} \mathrm{W}\right)$, Porto Colômbia $2\left(20^{\circ} 7^{\prime} 2.08^{\prime \prime} \mathrm{S} ; 48^{\circ} 28^{\prime} 49.78^{\prime \prime} \mathrm{W}\right)$, and Volta Grande $\left(20^{\circ} 7^{\prime} 38.86^{\prime \prime} \mathrm{S} ; 48^{\circ} 3^{\prime} 51.21^{\prime \prime} \mathrm{W}\right)$.

\subsection{Experimental Sections with Erosion Control Techniques}

The experimental units were installed on the margins of the reservoirs at the end of 2016 to evaluate different erosion control techniques (rigid, semi-rigid, and bioengineering, among others) that could reduce the silting of the reservoirs. The site was selected after field surveys (in June/July 2016) and fetch analyses that checked the incidence of winds and waves in the reservoirs. The latter considered the methodology proposed by Marques and Andrade [31] based on the method developed by Saville [32]. The fetch concept originated in atmospheric science applications, primarily related to forecasting oceanic wave heights generated by wind action. Fetch quantifies the transfer of wind energy to a specific location on the water surface by the speed inherent to the wind and the length of the winding track. In inland waters, the method developed by Saville is recommended by the US Army Coastal Engineering Research Center [31]. Information on wind speed in the region during the monitoring period is shown in Figure 2. The meteorological data were supplied by the Brazilian National Meteorological Institute (INMET). The meteorological station of reference is in the city of Conceição das Alagoas, MG (19 $\left.59^{\prime} 7.31^{\prime \prime} \mathrm{S} ; 48^{\circ} 9^{\prime} 3,36^{\prime \prime} \mathrm{W}\right)$.

The winds in the region have an average speed of $2.12 \mathrm{~m} / \mathrm{s}$. Most winds in the region are winds from north to south, followed by winds from the northeast. Classified by speed, $17.4 \%$ of winds are calm (less than $0.5 \mathrm{~m} / \mathrm{s}$ ), $66.7 \%$ are between 0.5 and $3.6 \mathrm{~m} / \mathrm{s}, 15.8 \%$ are between 3.6 and $8.8 \mathrm{~m} / \mathrm{s}$, and finally, $0.1 \%$ of winds in the region have a speed between 8.8 and $11.1 \mathrm{~m} / \mathrm{s}$.

Each UE was divided into a different number of sections, as seen in Figure 3. Each experimental section had a height between 1.5 and $2 \mathrm{~m}$ and an approximate area of $150 \mathrm{~m}^{2}$. Figure 3 shows the location of the sections in each experimental unit, and Table 2 identifies the type of technique used in each section. Moreover, a schematic profile of each of the techniques analyzed in this study is presented in Figure 4. Images of the general installation procedures of the techniques are available in Figure A1. 


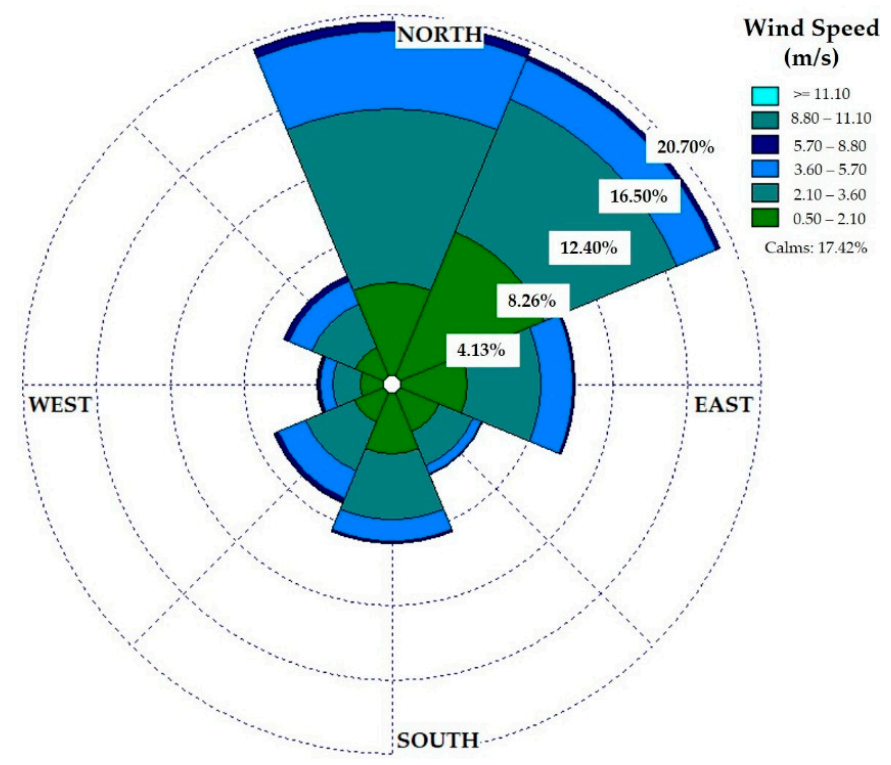

Figure 2. Wind strength and direction in the region, from January 2016 to September 2020.

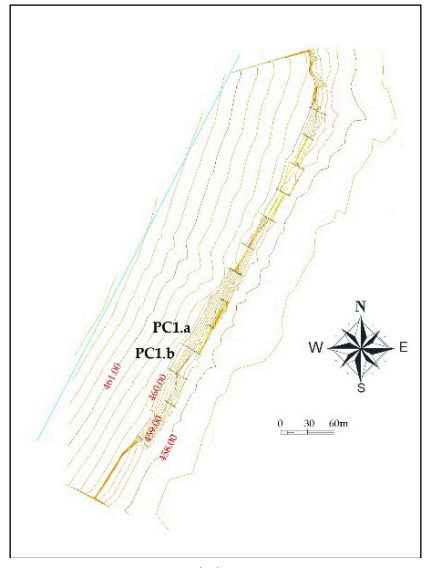

(a)

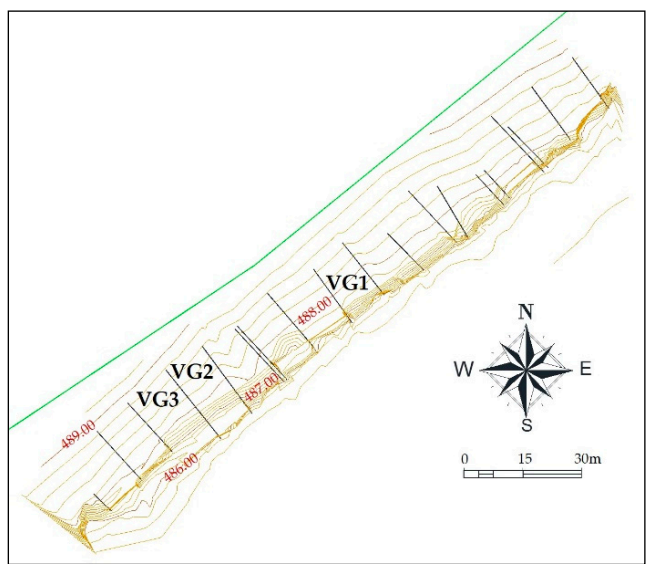

(b)

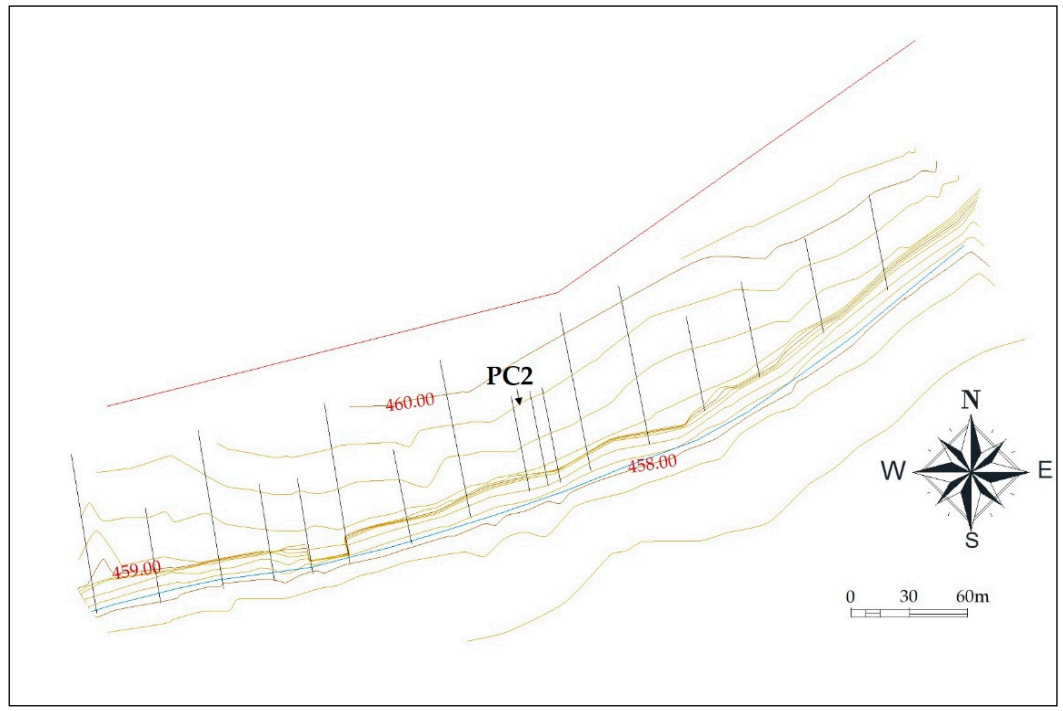

(c)

Figure 3. Identification of the sections installed in the HPP experimental units: (a) UE1 Porto Colômbia, (b) UE Volta Grande, and (c) UE2 Porto Colômbia. 
Table 2. Erosion control techniques evaluated and respective installation sites.

\begin{tabular}{cccc}
\hline \multirow{2}{*}{ Erosion Control Technique } & \multicolumn{3}{c}{ Section Installed } \\
\cline { 2 - 4 } & UE PC1 & UE PC2 & UE VG \\
\hline Geomat & PC1.b & - & VG1 \\
Geomat and Sack Gabion & PC1.a & PC2 & VG2, VG3 \\
\hline
\end{tabular}

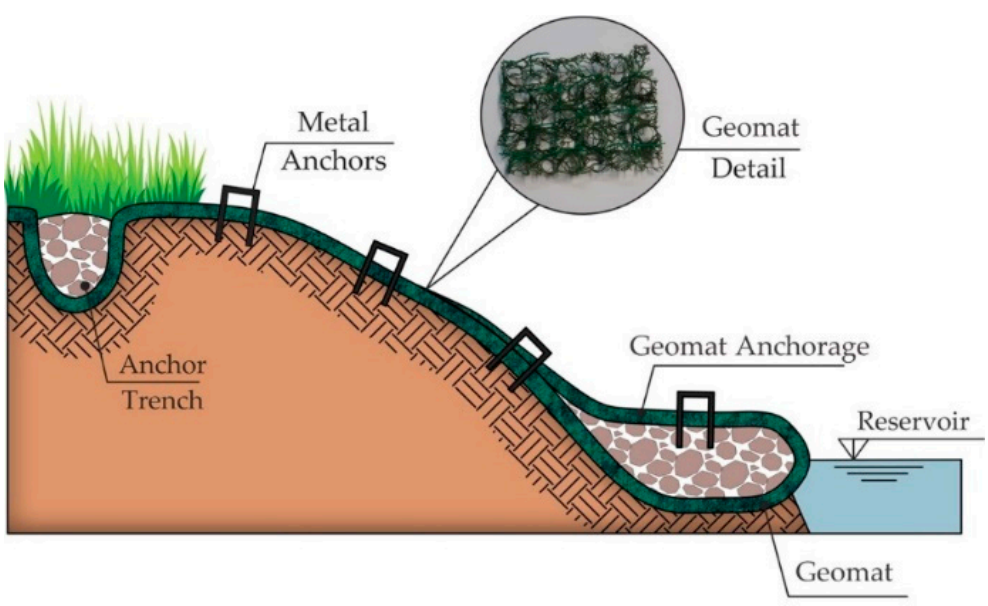

(a)

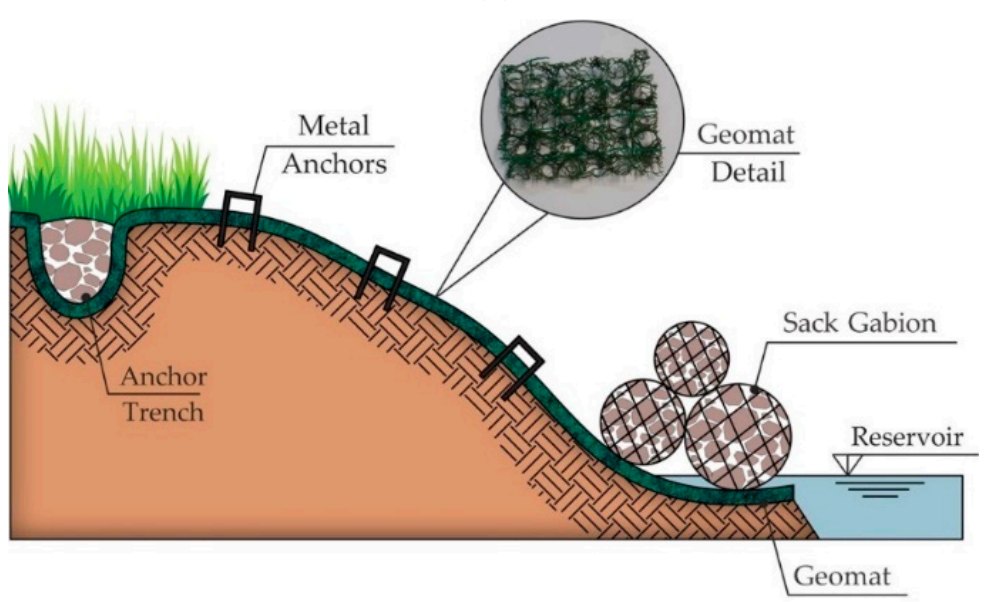

(b)

Figure 4. Schematic configuration profile of erosion control techniques: (a) geomat and (b) geomat and sack gabion.

\subsection{Geomat Characteristics}

The geomat used to control the erosion on the reservoir's margins is a three-dimensional geomat reinforced with synthetic geogrid. The central part is manufactured using polyethene, and the geogrid is manufactured with polyester filaments (Figure 5). The geomat has high flexibility and a void index of more than 90\%. Interlocking between the roots and the 3D geomat supports the shear forces generated by hydric erosion and stabilizes the subsurface soil [15]. The physical and mechanical properties of the geomat are presented in Table 3. 


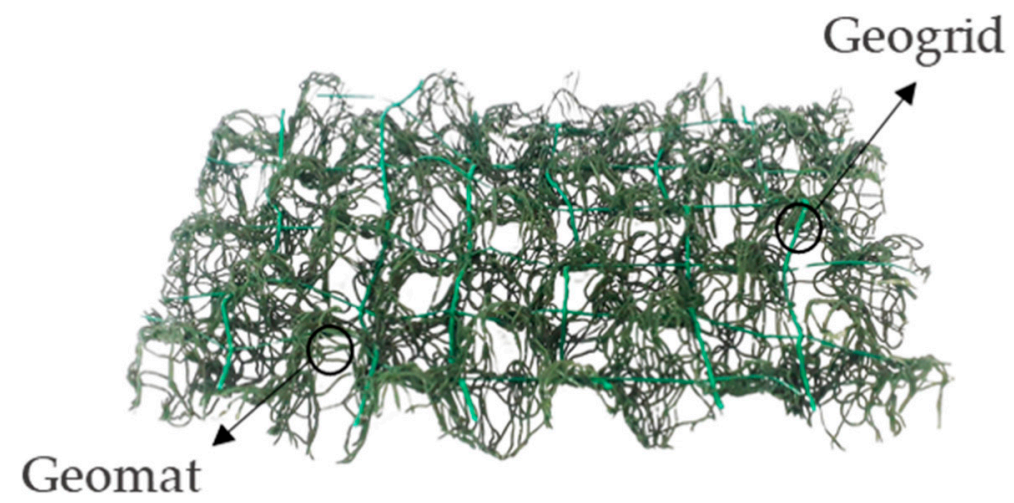

Figure 5. Geomat used in the erosion control techniques.

Table 3. Geomat properties.

\begin{tabular}{ccc}
\hline Properties & Test Method & Average Value \\
\hline Mass per unit area $\left(\mathrm{g} / \mathrm{m}^{2}\right)$ & ABNT NBR ISO 9864 [33] & 563 \\
\hline Thickness $(\mathrm{mm})$ & ABNT NBR ISO 9863-1 [34] & 12.45 \\
\hline $\begin{array}{c}\text { Tensile strength per unit } \mathrm{MD}^{1}(\mathrm{kN} / \mathrm{m}) \\
\text { Elongation at break } \mathrm{MD}^{1}(\%)\end{array}$ & ABNT NBR ISO 10319 [35] & 3.93 \\
\hline $\begin{array}{c}\text { Tensile strength per unit CD } \\
\text { Elongation at break } \mathrm{CD}^{2}(\mathrm{kN})\end{array}$ & ABNT NBR ISO 10319 [35] & 44.08 \\
\hline $\begin{array}{c}\text { Puncture Resistance }(\mathrm{kN}) \\
\text { Displacement }(\mathrm{mm})\end{array}$ & ABNT NBR ISO 12236 [36] & 3.33 \\
\hline
\end{tabular}

${ }^{1} \mathrm{MD}$, machine direction; ${ }^{2} \mathrm{CD}$, cross direction.

\subsection{Performance Evaluation of the Techniques}

The monitoring of each experimental unit's sections occurred periodically, including monthly visits from 2016 to February 2020. To evaluate the performance of the techniques installed in each section, six performance variables were defined, and a score was assigned to each variable analyzed (Table 4). The variables (performance matrix) implemented in this paper were defined in the study carried out by Galvão et al. [37] and used in the research by Aparicio Ardila et al. [21]. Scores ranging from 0 to 3 were assigned to each variable, as shown in Table 4 below. The six evaluated variables are numbered from V1 to V6: erosive spots/toe integrity on reservoir bank, vegetative cover growth, final structural integrity, need for maintenance, landscape integration/aesthetics, and finally, regrowth native vegetation top of the section.

Different analyses in water bodies have used differential bathymetry as a tool to try to quantify silting and sediment transport [38-40]. In this study, as in the study by Aparicio Ardila et al. [21], we have two bathymetric records corresponding to the initial monitoring after installing the techniques (in 2016) and the last one (in 2020) when the monitoring activities were completed.

The bathymetry study was carried out following the regulations of Brazilian entities such as the ANA (Brazilian National Water Agency), ANEEL (Brazilian Electricity Regulatory Agency), and Law 12.334/2010 [41]. Two bathymetric profiles spaced $5 \mathrm{~m}$ apart were obtained in each section: one at the beginning of the section (profile 1) and one at the end of the section (profile 2). The activities involved in the bathymetry study were (i) geo-referenced planialtimetric survey topobathymetry, (ii) recognition of the area, (iii) geo-referenced demarcation, (iv) altimetric determination, (v) preliminary design of the project, and (vi) topobathymetric survey in the margin areas and topographic survey in the slope protection areas. 
Table 4. Performance matrix of the evaluation.

\begin{tabular}{|c|c|c|}
\hline Variable & & Score \\
\hline \multirow{4}{*}{$\begin{array}{l}\text { V1 (Erosive spots/toe integrity on } \\
\text { reservoir bank) }\end{array}$} & 0 & High \\
\hline & 1 & Intermediate \\
\hline & 2 & Low \\
\hline & 3 & Inexistent \\
\hline \multirow{4}{*}{ V2 (Vegetative cover growth) } & 0 & Bare $(<30 \%)$ \\
\hline & 1 & Low vegetative cover (30 to $\leq 50 \%$ ) \\
\hline & 2 & Average vegetative cover $(>50-\leq 70 \%)$ \\
\hline & 3 & High vegetative cover $(>70-100 \%)$ \\
\hline \multirow{4}{*}{ V3 (Final structural integrity) } & 0 & Serious damage (>30\% of the total) \\
\hline & 1 & Average damage (10-30\% of the total) \\
\hline & 2 & Low level of damage ( $<10 \%$ of the total) \\
\hline & 3 & No damage \\
\hline \multirow{4}{*}{ V4 (Need for maintenance) } & 0 & High (> than 5 times) \\
\hline & 1 & Average ( 3 to 5 times) \\
\hline & 2 & Low (1-2 times) \\
\hline & 3 & No need \\
\hline \multirow{4}{*}{$\begin{array}{c}\text { V5 (Landscape } \\
\text { integration/aesthetics) }\end{array}$} & 0 & No integration with local landscape \\
\hline & 1 & Integration with local landscape after 2 years \\
\hline & 2 & Integration with local landscape after 4 years \\
\hline & 3 & Integration since the startup \\
\hline \multirow{4}{*}{$\begin{array}{l}\text { V6 (Regrowth native vegetation top } \\
\text { of the section) }\end{array}$} & 0 & Absence of native flora \\
\hline & 1 & Presence of $1-3$ native species \\
\hline & 2 & Presence of $3-5$ species \\
\hline & 3 & Presence of more than 5 native species \\
\hline
\end{tabular}

\subsection{Degradation Due to UV Radiation}

Geosynthetics, in general, use polymers as their raw material. Several atmospheric agents can degrade these polymers, among which the UV radiation present in sunlight stands out, as it is the type of radiation that most affects these materials [42]. The main mechanisms of degradation of polyethene (material from which the central part of the geomat is made) are UV degradation, thermal degradation, oxidative degradation, and the synergistic effects of these mechanisms co-occurring [43]. Figure 6 shows the monthly UV radiation (in $\mathrm{kWh} / \mathrm{m}^{2}$ ) and the maximum monthly temperature to which the geomats of the experimental sections were exposed.

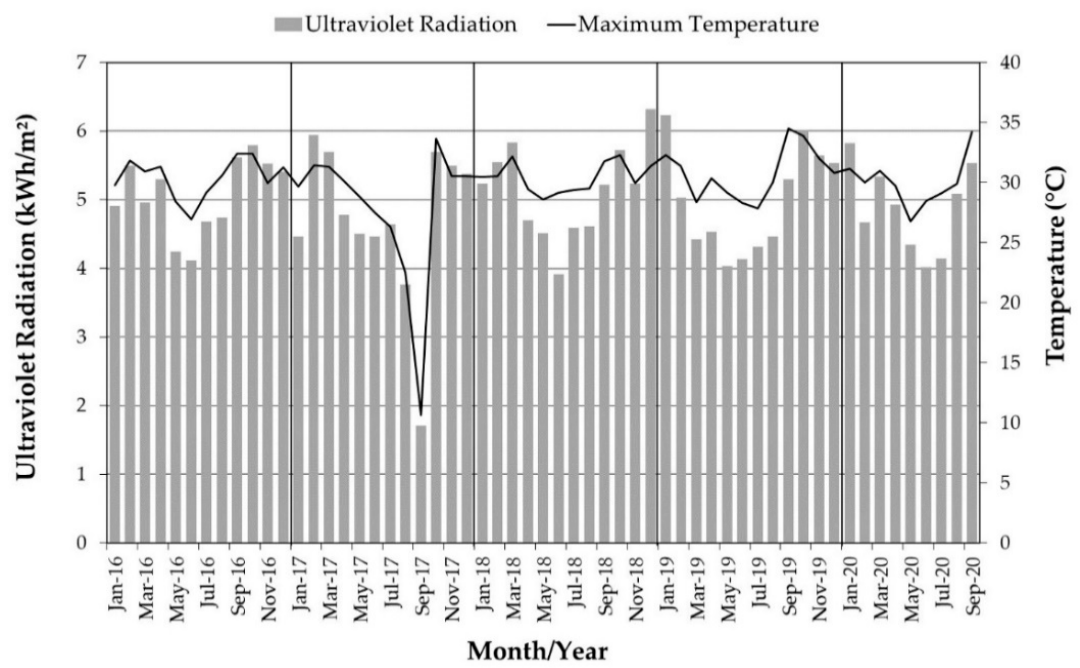

Figure 6. Meteorological information (UV radiation and maximum temperature). 
Geomat exposure to UV radiation was analyzed both in the field with samples collected at the end of monitoring the techniques and in the laboratory. In the laboratory, radiation aging tests (accelerated weathering) were carried out, adopting the exposure times commonly used in the literature (500 and $1000 \mathrm{~h}$ ). Accelerated weathering is used to recreate the radiation to which geosynthetic materials are exposed in the field in a shorter period (in the laboratory). However, correlating the laboratory exposure period with natural weathering (in the field) is challenging as UV weathering depends on many variables [44].

In the tests carried out at the Geosynthetic Laboratory at the University of São Paulo (USP) in São Carlos, Brazil, an Equilam weathering chamber, model EQUV 003 with UVA351 fluorescent lamps, was used, programmed to work in cycles of $20 \mathrm{~h}$ of ultraviolet light at $70{ }^{\circ} \mathrm{C}$ followed by $4 \mathrm{~h}$ of condensation at $50{ }^{\circ} \mathrm{C}$. For these tests, two geomat samples of $20 \times 30 \mathrm{~cm}$ were used: one for the 500-h exposure and the other for the 1000-h exposure. After exposure, samples of the aged material were collected for thermal analyses. The effects of aged samples and samples collected in the field were evaluated using virgin sample values as a reference.

\subsection{Geomat Thermal Analyses}

Thermoanalytical methods are used in many materials studies, especially in polymeric materials for characterization studies, observing curves, or even kinetic studies [45]. Geosynthetics are essentially made up of polymers and some additives incorporated in manufacturing to improve the behavior of these materials [46]. Thermoanalytical studies have shown beneficial and promising results in characterization and performance (durability) studies of geosynthetics. Among these thermoanalytical studies, studies have been carried out on non-woven geotextiles, e.g., [21,47], and on geomembranes, e.g., [48,49]. For the present study regarding the geomat, the differential scanning calorimetry (DSC) technique was chosen as a way of evaluating the behavior of the polymeric materials from which the geomat is manufactured by studying some thermal parameters [50].

The geomat consists of two parts (Figure 5): the structural part (geogrid) and the geomat. Therefore, thermal analyses were performed on each part to obtain a better evaluation result. Thus, the geomat was separated into the central part $(\mathrm{CP})$ and structural part (SP).

This study's thermoanalytical method was differential scanning calorimetry (DSC) following the ASTM D 3418 [51] standard and the principles of Ionashiro et al. [52]. The thermal analysis was carried out to study the samples' possible degradation processes by comparing endothermic or exothermic events for the samples in the intact (virgin) form, the samples aged in a UV aging chamber, and field samples. DSC enables us to study the physical or chemical properties of materials when subjected to temperature variations, which may be related to the decomposition of materials. The measurements were carried out with a DSC Q20 model TA Instrument (TA Instruments, New Castle, DE, USA). The analyses were performed at a $20^{\circ} \mathrm{C} \mathrm{min}-1$ heating rate under nitrogen purge gas with a flow of $50 \mathrm{~mL} \mathrm{~min}{ }^{-1}$. The samples with around $10 \mathrm{mg}$ were assessed in an aluminum crucible. The temperature ranged from 25 to $175^{\circ} \mathrm{C}$ for the $\mathrm{CP}$ samples and 25 to $300^{\circ} \mathrm{C}$ for the SP samples.

DSC parameter curves were used to observe material degradation by determination of melting point temperature (Tm), crystallization temperature (Tc), enthalpy of fusion $(\Delta \mathrm{H})$, and crystallinity degree, as indicated in Figure 7 below. 


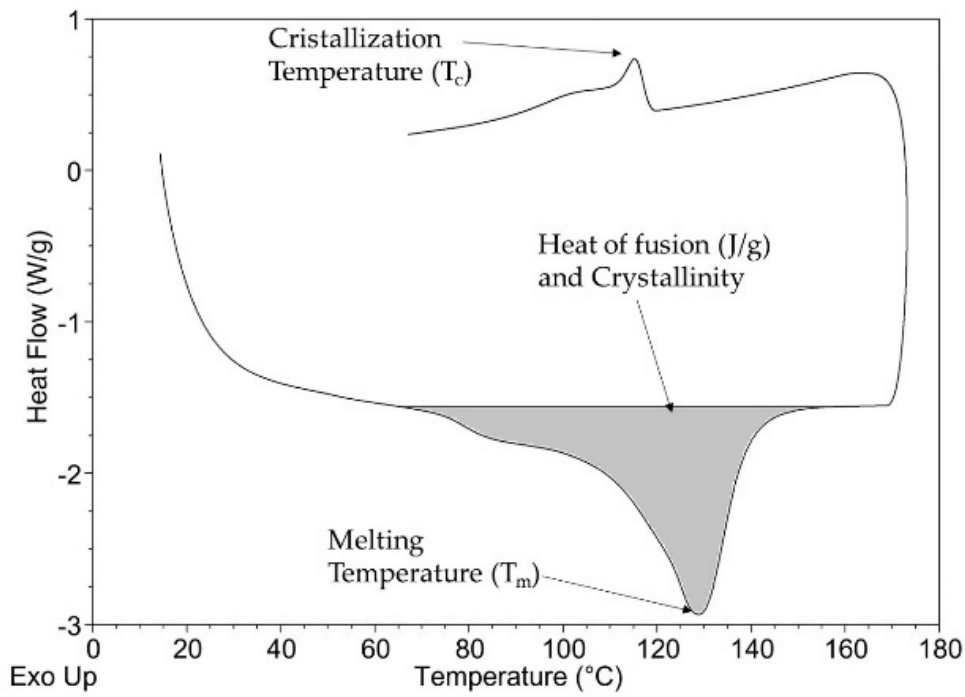

(a)

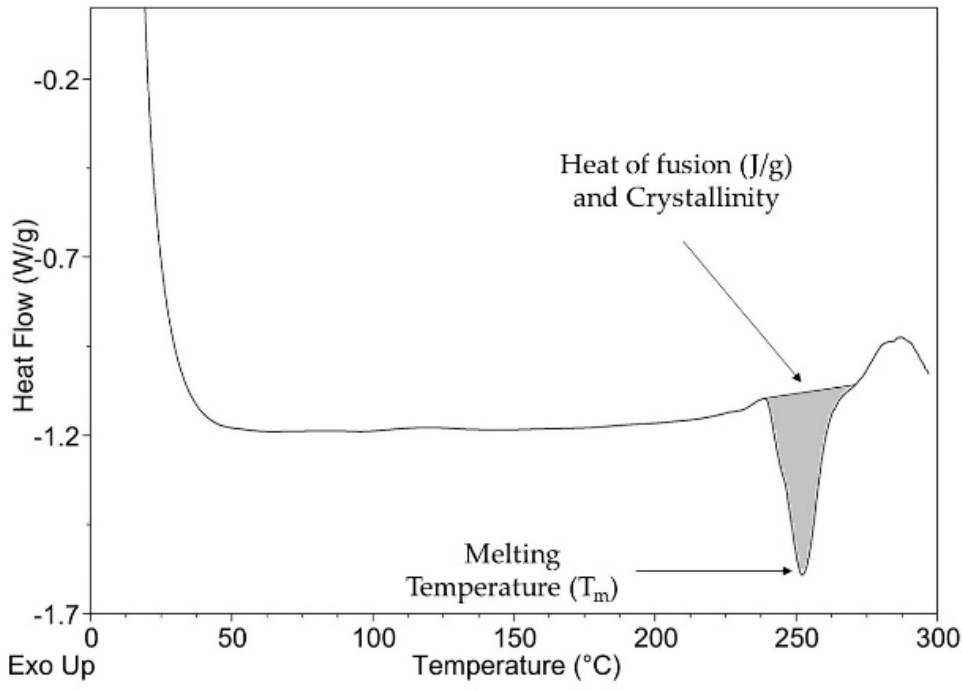

(b)

Figure 7. Differential scanning calorimetry (DSC): (a) central part (CP) sample; (b) structural part (SP) sample.

The melting enthalpy or enthalpy of fusion $(\Delta \mathrm{H})$ is equal to the area under the melting peak. It represents the polymer's crystallinity. The percentage of crystallinity is deduced by comparing a theoretical $\Delta \mathrm{H}$ for the $100 \%$ crystalline polymer $(285 \mathrm{~J} / \mathrm{g}$ for polyethylene and high density and $140 \mathrm{~J} / \mathrm{g}$ for polyester) [53].

\section{Results and Discussion}

\subsection{Performance Matrix}

The performance scores obtained in each experimental section, both total and per analyzed variable (Table 4), are shown in the graph in Figure 8. The experimental unit with the best qualitative performance of erosion control techniques was the VG experimental unit, followed by PC1. Analyzing by sections, the ones that presented the best qualitative performance used the techniques of geomat and sack geogrid (PC1.a, VG2, and VG3), except for the PC2 experimental section unit. These results indicate that bioengineering techniques are improved by implementing semi-rigid erosion control techniques, which have also been shown to be efficient in the work developed by Aparicio Ardila et al. [21] in the margins of the same reservoirs. In the present work, the semi-rigid erosion control 
techniques are represented by the geogrid sack. The low performance of the geomat in the PC2 section may be associated with the lack of adequate contact between the material and the soil surface (structural problems reported during the monitoring). The contact problems between geomat and soil reinforce the need to carefully install the product in the field [4], which in the case of the PC2 section influenced its performance since the clamps failed to fix the geomat properly to the reservoir margin.

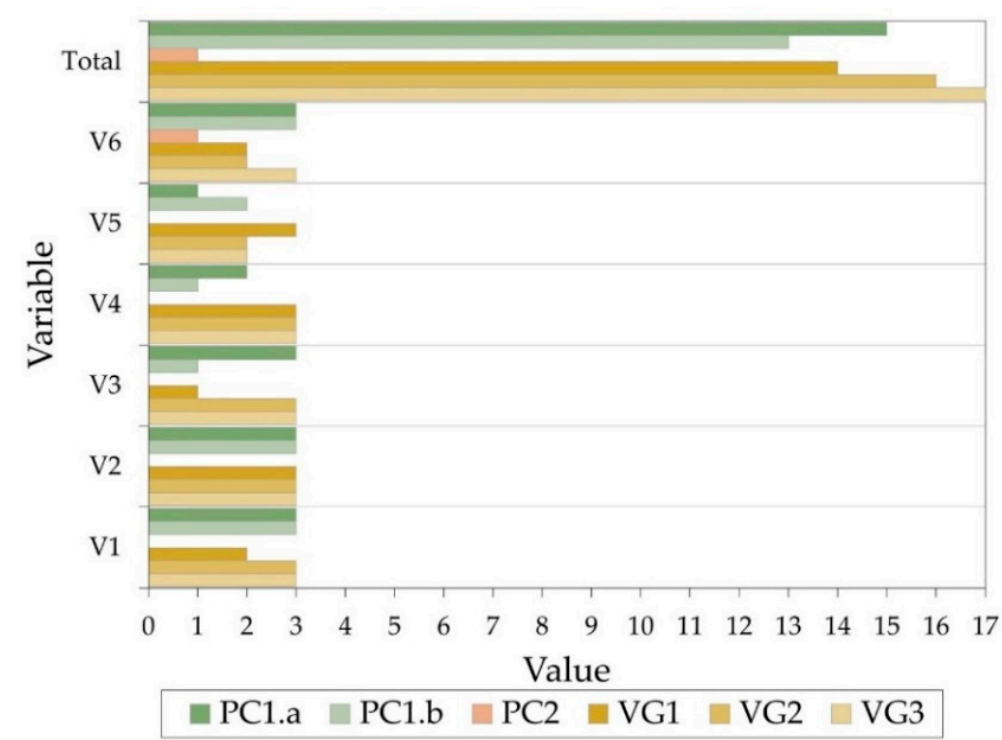

Figure 8. Performance of each section.

\subsection{Differential Bathymetry}

Examples of the initial and final cross profile 1 and profile 2 (PC1.a and PC2 sections) bathymetry are shown in Figure 9. Section PC2 (Figure 9b) is the only one that presented only one transversal profile. The values of the differential bathymetry by profile and section are shown in Table 5. It should be mentioned that vertical errors can be induced along with the bathymetry measures [54].

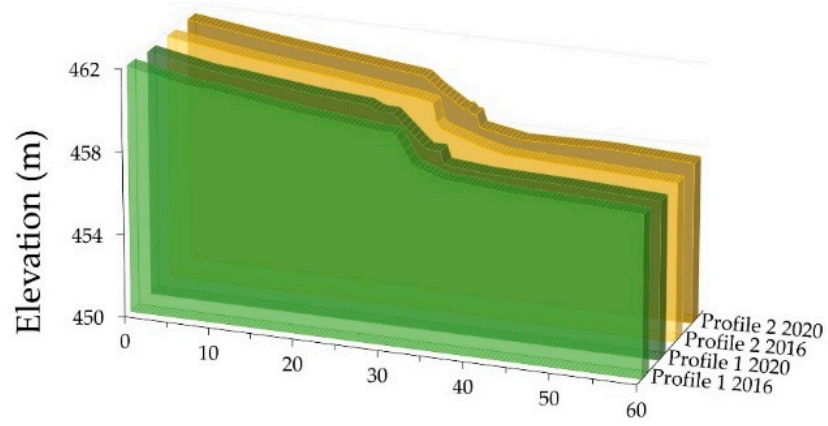

Distance (m)

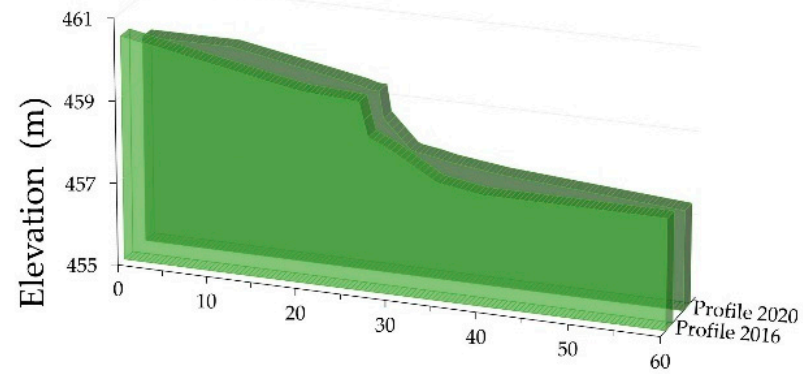

Distance (m)

(a)

(b)

Figure 9. Differential bathymetry: (a) PC1.a section; (b) PC2 section. 
Table 5. Maximum and minimum values of differential bathymetry in each section.

\begin{tabular}{cccc}
\hline Profile & Bathymetric Difference $(\mathrm{m})$ & Section & Bathymetric Difference (m) \\
\hline $\begin{array}{c}\text { Profile 1 PC1.a } \\
\text { Profile 2 PC1.a }\end{array}$ & $\begin{array}{l}-0.11 \text { to } 0.93 \\
-0.40 \text { to } 0.63\end{array}$ & PC1.a & -0.40 to 0.93 \\
\hline $\begin{array}{c}\text { Profile 1 PC1.b } \\
\text { Profile 2 PC1.b }\end{array}$ & $\begin{array}{l}-0.25 \text { to } 0.59 \\
-0.23 \text { to } 0.69\end{array}$ & PC1.b & -0.25 to 0.69 \\
\hline Profile 1 PC2 & -0.04 to 0.56 & PC2 & -0.04 to 0.56 \\
\hline $\begin{array}{c}\text { Profile 1 VG1 } \\
\text { Profile 2 VG1 }\end{array}$ & $\begin{array}{l}0.00 \text { to } 0.80 \\
-0.06 \text { to } 1.62\end{array}$ & VG1 & -0.06 to 1.62 \\
\hline $\begin{array}{l}\text { Profile 1 VG2 } \\
\text { Profile 2 VG2 }\end{array}$ & -1.16 to 0.76 & VG2 & -1.16 to 0.93 \\
\hline $\begin{array}{l}\text { Profile 1 VG3 } \\
\text { Profile 2 VG3 }\end{array}$ & $\begin{array}{l}-0.75 \text { to } 0.93 \\
-0.94 \text { to } 0.99\end{array}$ & \multirow{2}{*}{ VG3 } & -0.94 to 0.99 \\
\hline
\end{tabular}

In the differential bathymetry analysis (Table 5), the negative values suggest less deposition of sediments, and therefore, higher values indicate more significant sediment deposition in the reservoir. The maximum values of the bathymetric difference (by section) show that the experimental unit that had more sediment deposition in the tested period (2016 to 2020) was the VG, mainly in the only section of the experimental unit without the erosion control technique that includes the sack gabion (VG1). Of the three experimental units analyzed, the section with the least sediment deposition was $\mathrm{PC} 2$, despite presenting low qualitative performance (Figure 8).

\subsection{Differential Scanning Calorimetry (DSC)}

Table 6 shows the results obtained for the central part (CP) of the geomat, for the intact (virgin) samples, the samples exposed in a UV aging chamber for 500 and $1000 \mathrm{~h}$, and the samples collected in each experimental field section.

Table 6. Thermal properties of the central part (CP) samples of the geomat.

\begin{tabular}{ccccc}
\hline Sample & $\mathbf{T}_{\mathbf{m}}\left({ }^{\circ} \mathbf{C}\right)$ & $\mathbf{T}_{\mathbf{c}}\left({ }^{\circ} \mathbf{C}\right)$ & $\mathbf{\Delta H}_{\mathbf{m}}(\mathbf{J} / \mathbf{g})$ & Crystallinity $\left.\mathbf{~}^{\mathbf{1}} \mathbf{\%}\right)$ \\
\hline Virgin & 128.85 & 115.11 & 99.68 & 34.98 \\
UV 500 h & 129.89 & 115.05 & 102.5 & 35.96 \\
UV 1000 h & 133.68 & 113.86 & 81.59 & 28.63 \\
PC1.a & 129.67 & 114.70 & 105.9 & 37.17 \\
PC1.b & 128.29 & 114.62 & 82.57 & 28.97 \\
PC2 & 129.12 & 114.60 & 97.76 & 34.30 \\
VG1 & 129.19 & 114.53 & 107.3 & 37.63 \\
VG2 & 128.36 & 114.50 & 186.4 & 65.41 \\
VG3 & 126.41 & 114.95 & 133.0 & 46.67 \\
\hline
\end{tabular}

${ }^{1} \Delta \mathrm{H}=285 \mathrm{~J} / \mathrm{g}$ for $100 \%$ crystalline PE.

The fusion $\left(\Delta \mathrm{H}_{\mathrm{m}}\right)$ and crystallization temperature $\left(\mathrm{T}_{\mathrm{c}}\right)$ results obtained in the DSC analysis show that both the samples exposed in the aging chamber and the field samples presented values close to the virgin samples' results. The results indicated that there was no degradation of polymer chains in materials exposed to UV radiation. Regarding the melting temperature $\left(\mathrm{T}_{\mathrm{m}}\right)$, the highest variation found was $3.7 \%$ in the sample exposed to UV $1000 \mathrm{~h}$, and the lowest variation was $-1.9 \%$ in the VG3 sample. The values of heat of fusion $\left(\Delta \mathrm{H}_{\mathrm{m}}\right)$ and the percentage of crystallinity showed different variations, reaching values of $87 \%$ in the VG2 sample, which indicates a considerable variation in the crystalline structure.

Table 7 shows the results obtained for the structural part (SP) of the geomat for the intact (virgin) samples, the samples exposed in a UV aging chamber for 500 and $1000 \mathrm{~h}$, and the samples collected in each experimental field section. 
Table 7. Thermal properties of the structural part (SP) samples of the geomat.

\begin{tabular}{cccc}
\hline Sample & $\mathbf{T}_{\mathbf{m}}\left({ }^{\circ} \mathbf{C}\right)$ & $\boldsymbol{\Delta H}_{\mathbf{m}}(\mathbf{J} / \mathbf{g})$ & Crystallinity $\mathbf{~}^{\mathbf{1} \%)}$ \\
\hline Virgin & 254.27 & 24.32 & 17.37 \\
UV 500 h & 252.89 & 32.59 & 23.28 \\
UV 1000 h & 255.27 & 39.22 & 28.02 \\
PC1.a & 255.47 & 32.05 & 22.89 \\
PC1.b & 255.63 & 36.39 & 25.99 \\
PC2 & 254.88 & 19.99 & 14.28 \\
VG1 & 255.64 & 31.22 & 22.30 \\
VG2 & 255.75 & 18.81 & 13.43 \\
VG3 & 254.21 & 34.30 & 24.50 \\
\hline
\end{tabular}

${ }^{1} \Delta \mathrm{H}=140 \mathrm{~J} / \mathrm{g}$ for $100 \%$ crystalline PET.

The structural part of the geomat (SP) did not show thermal stability for the crystallization temperature (Tc) analysis; therefore, this parameter was not considered in these samples. As observed in the results for the central part (CP) of the geomat (Table 6), the results for the structural part (SP) (Table 7) indicated that there was no degradation of the sample. The melting temperature values $(\mathrm{Tm})$ in Table 7 showed minimal variations below $0.5 \%$. The heat of fusion $(\Delta \mathrm{Hm})$ and percentage of crystallinity showed an increasing tendency for samples exposed in the UV aging chamber (UV $500 \mathrm{~h}$ and UV $1000 \mathrm{~h}$ ) and random values for field samples. There was a maximum variation of $64 \%$ in the sample of the structural part (SP) UV $1000 \mathrm{~h}$ and a variation of $-22 \%$ in the sample of the structural part (SP) of section VG2.

The sample from section VG2 in the two parts of the geomat (CP and SP) showed significant variations in the fusion heat $(\Delta \mathrm{Hm})$ values and percentage of crystallinity, which could be attributed to the application conditions (reservoir margin) where the geomat was submerged most of the time. These variations could also be related to the incorporation of impurities from the environment in the material structure. Studies by Abdelaal and Rowe [55] identified a degradation in polyethene geomembranes in contact with chlorinated water. The study indicated that some water characteristics can cause the decomposition or degradation of polymers that comprise the geosynthetics in the long term. In the present work, considering the thermal analysis results, no degradation was found due to the geomat contact with the reservoir water.

\section{Conclusions}

The present contribution, considering the geomat performance over four years of monitoring, through a qualitative evaluation matrix and differential bathymetry, enabled us to confirm the long-term efficiency of the examined geomats after a real service. Moreover, the effect of UV radiation on the degradation of geomats installed under natural conditions, as well as under accelerated conditions, was observed using differential scanning calorimetry (DSC).

In general, the results indicated that there was no significant difference in performance between using the erosion control technique consisting only of geomat and the technique consisting of geomat and sack gabion. However, a difference in the complexity and costs of the erosion control techniques is evident, as they increase when the sack gabion technique is added.

Although the VG experimental unit was the one with the best qualitative performance, it was the one with the highest sediment disposition at the margin, which makes it clear that the specific conditions of the place, such as the effect of wind and wave incidence, are of great importance when an erosive process on the reservoir margins needs to be controlled. 
The sample in section VG2 was the one that most showed variations in the DSC analyses and was also one of the sections with a more significant sediment arrangement on its margins, which indicates that the sediments had chemical characteristics that allowed their incorporation into the geomat polymer material.

For future work, we highlight the need to carry out hydrodynamic studies to improve the knowledge about the lithodynamic and morphodynamic processes to which the reservoir margins are exposed.

Author Contributions: The individual contributions of each author are highlighted as follows: conceptualization: M.P.d.L.; data curation: M.A.A.A., R.D.d.S.J. and C.A.V.; formal analysis: M.A.A.A. and C.A.V.; funding acquisition: M.P.d.L.; investigation: M.A.A.A., C.A.V., M.S.S. and A.T.C.; methodology: M.A.A.A. and A.T.C.; project administration: M.P.d.L.; software: A.T.C.; supervision: J.L.d.S.; validation: M.A.A.A.; visualization: R.D.d.S.J.; writing—original draft: M.P.d.L. and M.A.A.A.; writing-review \& editing: M.P.d.L., M.S.S. and J.L.d.S. All authors have read and agreed to the published version of the manuscript.

Funding: This research was funded by the Agência Nacional de Energia Elétrica (ANEEL; PD-03941603/2016) and the Coordenação de Aperfeiçoamento de Pessoal de Nível Superior (CAPES; 001).

Institutional Review Board Statement: Not applicable.

Informed Consent Statement: Not applicable.

Data Availability Statement: Data sharing is not applicable to this article.

Acknowledgments: The authors would like to thank the University of São Paulo and the Eletrobras FURNAS community for the support provided to the research activities reported in this paper and Agência Nacional de Energia Elétrica (ANEEL; National Agency of Electric Energy) for promoting this research (PD-ANEEL number 0394-1603/2016). This study was financed in part (support granted to the second author) by the Brazilian Federal Agency for Support and Evaluation of Graduate Education (Coordenação de Aperfeiçoamento de Pessoal de Nível; CAPES) Finance Code 001.

Conflicts of Interest: The authors declare that they have no known competing financial interests or personal relationships that could have appeared to influence the work reported in this paper. Thus, the authors declare no conflict of interest. Moreover, the funders had no role in the design of the study; in the collection, analyses, or interpretation of data; in the writing of the manuscript; or in the decision to publish the results.

\section{Appendix A}

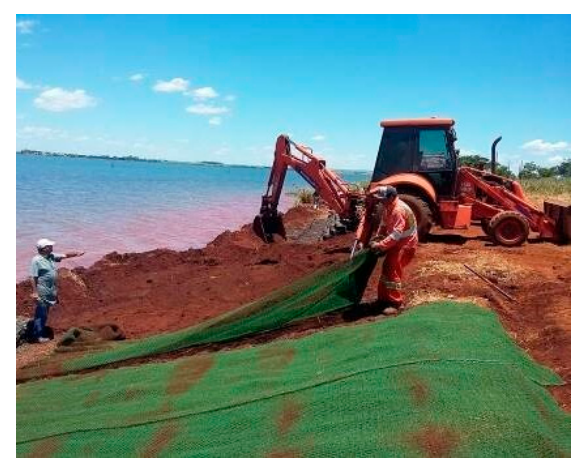

(a)

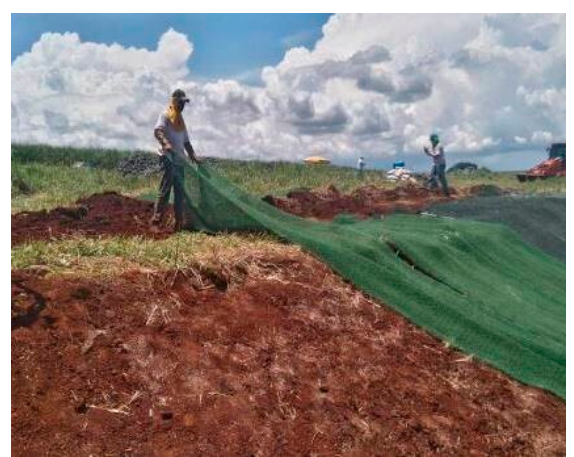

(b)

Figure A1. Cont. 


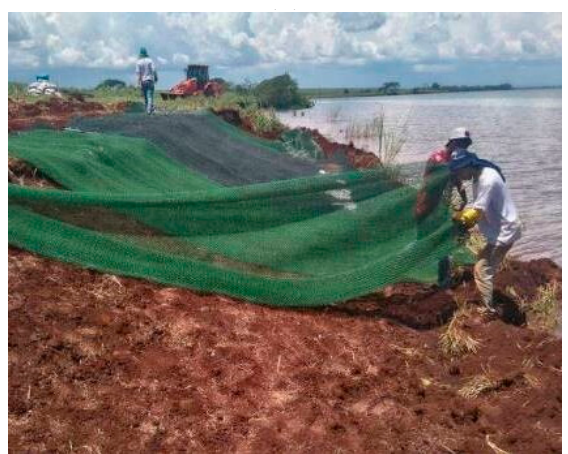

(c)

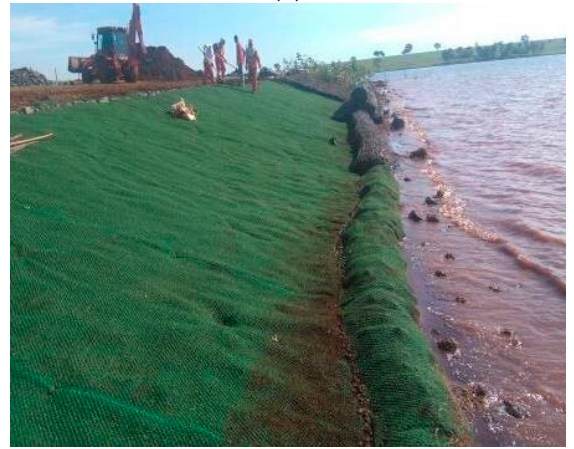

(e)

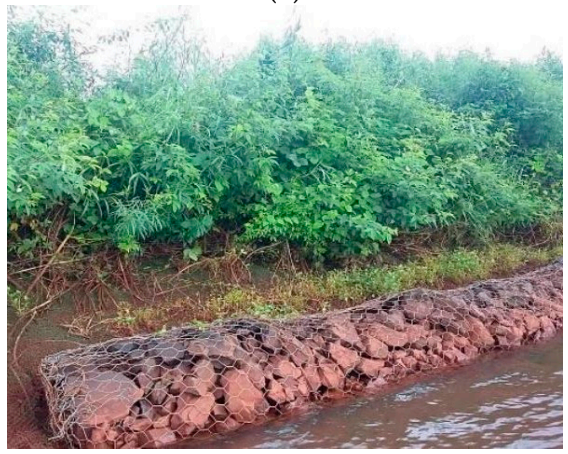

(g)

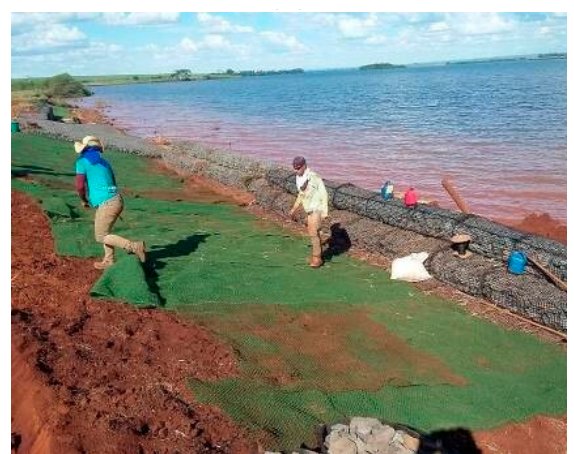

(d)

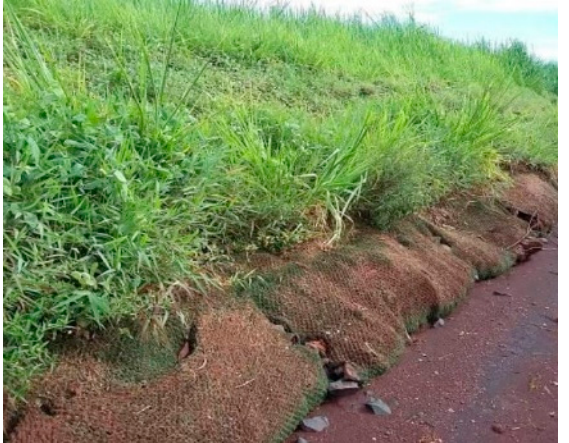

(f)

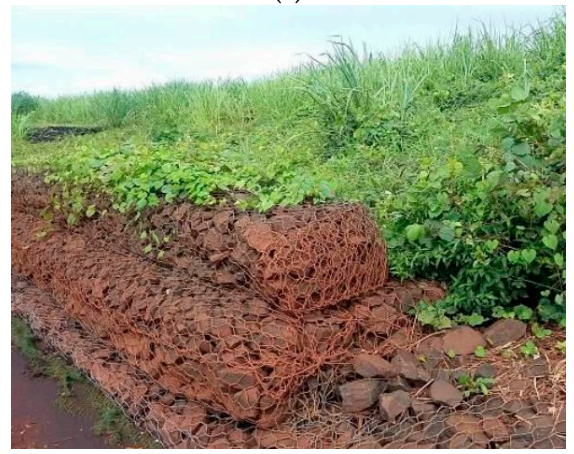

(h)

Figure A1. General installation procedures of the techniques: (a) mechanical reshaping of the margins, (b) construction of the anchor trench, (c) margin anchorage of the geomat, (d) sack gabion installation under the geomat, (e) final installation of the geomat erosion control technique, (f) geomat erosion control technique after two years of installation, $(\mathrm{g})$ geomat and sack gabion after two years of installation, and (h) geomat and sack gabion after four years of installation.

\section{References}

1. Theisen, M.S. The role of geosynthetics in erosion and sediment control: An overview. Geotext. Geomembr. 1992, 11, 535-550. [CrossRef]

2. Wilson, G.V.; Wells, R.; Kuhnle, R.; Fox, G.; Nieber, J. Sediment detachment and transport processes associated with internal erosion of soil pipes. Earth Surf. Proc. Land. 2018, 43, 45-63. [CrossRef]

3. Panagos, P.; Borrelli, P.; Poesen, J.; Ballabio, C.; Lugato, E.; Meusburger, K.; Montanarellaa, L.; Alewellb, C. The new assessment of soil loss by water erosion in Europe. Environ. Sci. Policy 2015, 54, 438-447. [CrossRef]

4. Melo, M.T.S.; Palmeira, E.M.; Santos, E.C.G.; da Luz, M.P. Geosynthetic performance against slope erosion caused by high intensity rainfall. Geosynth. Int. 2021, 1-14. [CrossRef]

5. Paz, F.E.; Flor-Paz, P.; Almanzor, N.; Marcos, M.C.M. Performance evaluation of soil erosion control geotextile materials on road cut slope. In Proceedings of the 2018 World Congress on Advances in Civil, Environmental, \& Materials Research (ACEM18) Songdo Convensia, Incheon, Korea, 27-31 August 2018.

6. Moore, H.M.; Fox, H.R.; Elliott, S. Land Reclamation-Extending Boundaries: Proceedings of the 7th International Conference; CRC Press: Runcorn, UK, 2003.

7. Gyssels, G.; Poesen, J.; Bochet, E.; Li, Y. Impact of plant roots on the resistance of soils to erosion by water: A review. Prog. Phys. Geogr. 2005, 29, 189-217. [CrossRef] 
8. Koerner, G.R.; Hsuan, Y.G.; Koerner, R.M. The durability of geosynthetics. In Geosynthetics in Civil Engineering; Sarsby, R.W., Ed.; Woodhead Publishing Limited and CRC Press LLC: Cambridge, UK, 2007; pp. 36-65.

9. Broda, J.; Grzybowska-Pietras, J.; Nguyen, G.; Gawlowski, A.; Laszczak, R.; Przybylo, S. Application of recycled fibres and geotextiles for the stabilisation of steep slopes. IOP Conf. Ser. Mater. Sci. Eng. 2017, 254, 192005. [CrossRef]

10. Gupta, S.; GuhaRay, A.; Kar, A.; Komaravolu, V.P. Performance of alkali-activated binder-treated jute geotextile as reinforcement for subgrade stabilization. Int. J. Geotech. Eng. 2018, 15, 299-312. [CrossRef]

11. Prambauer, M.; Burgstaller, C.; Eicher, M.; Hofmann, H. The use of biodegradable polyesters in seasonal geotextiles. Geotechnik 2020, 43, 26-30. [CrossRef]

12. Vianna, V.F.; Fleury, M.P.; Menezes, G.B.; Coelho, A.T.; Bueno, C.; da Silva, J.L.; Luz, M.P. Bioengineering Techniques Adopted for Controlling Riverbanks' Superficial Erosion of the Simplício Hydroelectric Power Plant, Brazil. Sustainability 2020, $12,7886$. [CrossRef]

13. Pinzani, G.P.; Sauli, G. Long term efficiency of erosion control geomats. In Proceedings of the 8th International Conference on Geosynthetics (8ICG), Yokohama, Japan, 18-22 September 2006; Volumes 1-4, pp. 737-740.

14. Bischetti, G.B.; Dio, M.D.F.; Florineth, F. On the Origin of Soil Bioengineering. Landsc. Res. 2012, 39, 583-595. [CrossRef]

15. Tan, H.; Chen, F.; Chen, J.; Gao, Y. Direct shear tests of shear strength of soils reinforced by geomats and plant roots. Geotext. Geomembr. 2019, 47, 780-791. [CrossRef]

16. Lejcuś, K.; Dabrowska, J.; Garlikowski, D.; Śpitalniak, M. The application of water-absorbing geocomposites to support plant growth on slopes. Geosynth. Int. 2015, 22, 452-456. [CrossRef]

17. Xu, Y.; Li, L.; Amini, F. Slope stability analysis of earthen levee strengthened by high performance turf reinforcement mat under hurricane overtopping flow conditions. Geotech. Geol. Eng. 2012, 30, 893-905. [CrossRef]

18. Koerner, R.M. (Ed.) Geosynthetics in Filtration, Drainage and Erosion Control; Elsevier: Amsterdam, The Netherlands, 2013.

19. Nguyen, T.S.; Likitlersuang, S.; Jotisankasa, A. Influence of the spatial variability of the root cohesion on a slope-scale stability model: A case study of residual soil slope in Thailand. Bull. Eng. Geol. Environ. 2019, 78, 3337-3351. [CrossRef]

20. Wang, G.Y.; Sun, G.R.; Li, J.K.; Li, J. The experimental study of hydrodynamic characteristics of the overland flow on a slope with three-dimensional Geomat. J. Hydrodynam. B 2018, 30, 153-159. [CrossRef]

21. Ardila, M.A.A.; dos Santos Junior, R.D.; Kobelnik, M.; Valentin, C.A.; Schliewe, M.S.; Coelho, A.T.; da Silva, J.L.; da Luz, M.P. Semi-Rigid Erosion Control Techniques with Geotextiles Applied to Reservoir Margins in Hydroelectric Power Plants, Brazil. Water 2021, 13, 500. [CrossRef]

22. Hashim, Z.E.; Al-Madhhachi, A.S.T.; Alzubaidi, L.A. Behavior of soil erodibility parameters due to biological soil crusts using jet erosion tests. Ecol. Eng. 2020, 153, 105903. [CrossRef]

23. Silva, P.O. Avaliação da Efetividade dos Projetos de Recuperação de Mata Ciliar Contra a Atuação das Ondas nos Processos Erosivos das Margens do Reservatório Volta Grande (MG/SP). Master's Thesis, Universidade Federal de Ouro Preto, Ouro Preto, MG, Brazil, 2020.

24. Larrabure, S.P. O fenômeno da segunda residência: O caso do rio Grande entre os estados de São Paulo e Minas Gerais. GEOUSP Espaço. Tempo. 2009, 26, 93-106. [CrossRef]

25. Alvares, C.A.; Stape, J.L.; Sentelhas, P.C.; Gonçalves, J.D.M.; Sparovek, G. Köppen's climate classification map for Brazil. Meteorol. Z. 2013, 22, 711-728. [CrossRef]

26. Brazilian Association of Technical Standards. NBR 6458: Gravel Grains Retained on the 4,8 mm Mesh Sieve-Determination of the Bulk Specific Gravity, of the Apparent Specific Gravity and ofWater Absorption; ABNT: Rio de Janeiro, Brazil, 2016; p. 14.

27. Brazilian Association of Technical Standards. NBR 7181: Soil—Grain Size Analysis; ABNT: Rio de Janeiro, Brazil, 2016 ; p. 16.

28. ASTM D 2487-17: Standard Practice for Classification of Soils for Engineering Purposes (Unified Soil Classification System); ASTM International: West Conshohocken, PA, USA, 2017.

29. Brazilian Association of Technical Standards. NBR 6459: Soil—Liquid Limit Determination; ABNT: Rio de Janeiro, Brazil, 2016 ; p. 9.

30. Brazilian Association of Technical Standards. NBR7180: Soil_Plasticity Limit Determination; ABNT: Rio de Janeiro, Brazil, 2016; p. 7.

31. Marques, M.; Andrade, F.O. Automated computation of two-dimensional fetch fields: Case study of the Salto Caxias reservoir in southern Brazil. Lake Reserv. Manag. 2017, 33, 62-73. [CrossRef]

32. Saville, T. The Effect of Fetch Width on Wave Generation; US Beach Erosion Board, U.S Army Corps of Engineers (USACE): Mississippi, FL, USA, 1954.

33. Brazilian Association of Technical Standards. ABNT NBR ISO 9864: Geosynthetics_-Test Method for the Determination of Mass per Unit Area of Geotextiles and Geotextile-Related Products; ABNT: Rio de Janeiro, Brazil, 2013.

34. Brazilian Association of Technical Standards. ABNT NBR ISO 9863-1: Geosynthetics—Determination of Thickness at Specified Pressures Part 1: Single Layers; ABNT: Rio de Janeiro, Brazil, 2013.

35. Brazilian Association of Technical Standards. ABNT NBR ISO 10319: Geosynthetics—Wide-Width Tensile Test; Associação Brasileira de Normas Técnicas: Rio de Janeiro, RJ, Brazil, 2013.

36. Brazilian Association of Technical Standards. ABNT NBR ISO 12236: Geosynthetics—Static Puncture Test (CBR test); ABNT: Rio de Janeiro, Brazil, 2006.

37. Galvão, T.C.D.B.; Coelho, A.T.; De Menezes, G.B.; De Fonseca, Ê.M.B. Study of Erosion Control Techniques Applied to Hydroelectric Power Plants Reservoir Margins. Athens. J. Sci. 2018, 5, 329-342. [CrossRef] 
38. Brasington, J.; Langham, J.; Rumsby, B. Methodological sensitivity of morphometric estimates of coarse fluvial sediment transport. Geomorphology 2003, 53, 299-316. [CrossRef]

39. Li, M.Z.; King, E.L. Multibeam bathymetric investigations of the morphology of sand ridges and associated bedforms and their relation to storm processes, Sable Island Bank, Scotian Shelf. Mar. Geol. 2007, 243, 200-228. [CrossRef]

40. Bures, L.; Sychova, P.; Maca, P.; Roub, R.; Marval, S. River Bathymetry Model Based on Floodplain Topography. Water 2019, 11, 1287. [CrossRef]

41. LAW, National Dam Safety Policy; Brazilian Law 12334/2010. Available online: http://www.planalto.gov.br/ccivil_03/_ato20072010/2010/lei/112334.htm (accessed on 28 February 2021).

42. Lopes, M.P.; de Lurdes Lopes, M. A Durabilidade dos Geossintéticos; FEUP Edições: Porto, Portugal, 2010.

43. Lavoie, F.L.; Kobelnik, M.; Valentin, C.A.; Silva, J.L.D. Durability of HDPE geomembranes: An overview. Quim. Nova 2020, 43, 656-667. [CrossRef]

44. Scheirs, J. A Guide to Polymeric Geomembranes: A Practical Approach; John Wiley \& Sons: West Sussex, UK, 2009.

45. Costa, H.M.D.; Ramos, V.D.; Andrade, M.C.D.; Nunes, P.D.S.R.Q. Análise térmica e propriedades mecânicas de resíduos de polietileno de alta densidade (PEAD). Polimeros 2016, 26, 75-81. [CrossRef]

46. Vertematti, J.C. Manual Brasileiro de Geossintéticos; Editora Blucher: Sao Paolo, Brazil, 2015.

47. Valentin, C.A.; Kobelnik, M.; Franco, Y.B.; Lavoie, F.L.; da Silva, J.L.; Luz, M.P. Study of the ultraviolet effect and thermal analysis on polypropylene nonwoven geotextile. Materials 2021, 14, 1080. [CrossRef] [PubMed]

48. Lavoie, F.L.; Valentin, C.A.; Kobelnik, M.; da Silva, J.L.; Lopes, M.D.L. HDPE Geomembranes for Environmental Protection: Two Case Studies. Sustainability 2020, 12, 8682. [CrossRef]

49. Valentin, C.A.; da Silva, J.L.; Kobelnik, M.; Ribeiro, C.A. Thermoanalytical and dynamic mechanical analysis of commercial geomembranes used for fluid retention of leaching in sanitary landfills. J. Therm. Anal. Calorim. 2019, 136, 471-481. [CrossRef]

50. Schick, C. Differential scanning calorimetry (DSC) of semicrystalline polymers. Anal. Bioanal. Chem. 2009, 395, 1589-1611. [CrossRef]

51. ASTM D 3418-Standard Test Method for Transition Temperatures and Enthalpies of Fusion and Crystallization of Polymers by Differential Scanning Calorimetry; ASTM International: West Conshohocken, PA, USA, 2015.

52. Ionashiro, M.; Caires, F.J.; Gomes, D.J.C. Giolito: Fundamentos da termogravimetria e análise térmica diferencial/calorimetria exploratória diferencial. São Paulo Giz 2005, 1, 80.

53. Rigo, J.M.; Rollin, A.L. (Eds.) Geomembranes-Identification and Performance Testing; CRC Press: Boca Raton, FL, USA, 1990.

54. Latapy, A.; Héquette, A.; Pouvreau, N.; Weber, N.; Robin-Chanteloup, J.B. Mesoscale morphological changes of nearshore sand banks since the early 19th century, and their influence on coastal dynamics, Northern France. J. Mar. Sci. Eng. 2019, 7, 73. [CrossRef]

55. Abdelaal, F.B.; Rowe, R.K. Degradation of an HDPE geomembrane without HALS in chlorinated water. Geosynth. Int. 2019, 26, 354-370. [CrossRef] 